\title{
Rents, Administrative Sanctions and Conventional Corruption-Control Approach: Evidence from the Prevention of Corruption Act, India.
}

Kannan Perumal ( $\square$ kannan.ips@gmail.com )

Bihar police https://orcid.org/0000-0002-6238-2943

\section{Research Article}

Keywords: administrative approvals, anti-corruption enforcement, discretions, Rents, Rent seeking, public authorities

Posted Date: June 22nd, 2021

DOl: https://doi.org/10.21203/rs.3.rs-642201/v1

License: (c) (i) This work is licensed under a Creative Commons Attribution 4.0 International License.

Read Full License 


\section{Abstract}

This study challenges the argument that making it mandatory for the anti-corruption agencies to obtain prior administrative approvals from public authorities before detecting and prosecuting the corrupt can bring-in efficiency in corruption control. Applying the political economy concepts rents and rent seeking, this study explores the intricate relationships that exist between discretions available with the public authorities and their decisions to allow the anti-corruption enforcement to detect and prosecute public servants in corruption cases. Issue of similar facts getting differently appreciated by different public authorities has also been brought out by this study. This study argues that prior approvals by public authorities in high discretionary and low risk environments can promote rent seeking behaviour in public organizations. Findings of this study shows that limiting the discretions of authorities that decide administrative approvals and holding them accountable for their decisions can be the conditions critical for efficient anti-corruption enforcement in India.

\section{Rents, Rent Seeking And Corruption}

Rents and rent-seeking are both ubiquitous and inevitable, and as long as there are rents there will be rentseeking, says Medema.S (2015). Any state policy like, regulations, subsidy, law etc., that results in incremental benefit to individuals or groups is a rent. Also, preferential treatments, lobbying (Lambsdorff, 2002), restrictions (Khan M, 2006) are forms of rents. Essentially, rents are created for making reallocation of resources in the society and when the state undertakes efficient measures rent allocations can result in desired outcomes (Fischer, 2004). Rent seeking, on the other hand, is about influencing the state policy outcome by spending resources. The most common rent-seeking behaviors include bribery, lobbying and preferential treatments (Mbaku J.M, 2003). Institutional economists see rent seeking as individual maximizing behavior that bears social cost because, a definite part of the resource is spent for transferring wealth rather than in the creation of new wealth. For them, rent seeking is socially wasteful (Tullock, 1993; Krueger, 1994). Rent seeking as unwanted by product of rents has been studied by Fischer (2004). His study is about the movement of state activity from allocation of resources for addressing externalities to illegal allocations facilitating state capture by the powerful. These political economy concepts have widely been applied in anti-corruption research and for devising corruption control tools as well.

Corruption, by standard definitions, is the outcome of agreement between actors to the deal for exchange of favour and bribe; and by nature, it's is a monopolistic form of rent seeking (Lambsdorff, 2007). Rent seeking becomes corruption when preferential treatment is limited to a few who can influence those who allocate resources. For Khan (2007), it is the ability of agent to allocate resources by exercising the discretionary powers that enables him to demand bribe. In order to demand or to increase bribe the agent can apply \& increase the red tape, jump the queue, collude with the supervisor etc., and such behaviors can cause or be the result of corruption. Also, the supervisor can abuse his discretions by colluding with or by ignoring corrupt behaviors of the agent. Situations where principal is not principled (Klitgaard, 1998) and where the principal is not determined to control corruption (Perumal, 2019) can deepen the problem; 
and such scenarios can benefit the corrupt in different ways. The problem gets complicated when the principal enjoys absolute discretion in allowing the agent getting detected and prosecuted by the anticorruption enforcement for his corrupt deals. This context based work attempts to study how the discretions available with the supervisors (principals) in allowing the public servants to get detected and prosecuted on charges of corruption facilitate unregulated rent allocations, and their impact on Indian anti-corruption enforcement.

\section{Corruption, Corruption Control And Governance}

Corruption has been found to be undermining governance and distorting the policy priorities (Blackburn, et al., n.d). By impacting economic efficiency and resource allocation, corruption negatively impacts growth. Evidently, the most of the developing countries continue to have high corruption levels and in spite of multiple anti-corruption interventions in the past three decades, corruption remains a serious policy challenge as such interventions have produced very limited results. While explaining the reasons for prevalence of high levels of corruption, Khan M, (2006) argues that the presence of certain structural drivers in governance makes corruption control difficult irrespective of the level of economic performance. This view suits more in the context of developing countries as even fast growing developing economies have high corruption levels. Unregulated rent allocations \& illegal rent seeking, lack of rule following behavior (Khan M, 2006), inadequately designed rules (Perumal K, 2019) etc., have been found to be causing and sustaining corruption. Such structural drivers, by making anti-corruption interventions less effective, undo the government's ability to correct the externalities (Olken \& Pande, 2012). Experience of developed countries show that regulating resource allocations and rent seeking can help to reduce corruption. It is essentially about building the state capacity. But, building such a capability is long drawn process in developing countries because of weak state apparatus and corruption control cannot wait. The ideas of good governance and sustainable development goals which are being touted to be preconditions for development compel the states to put rule of law, corruption control and development at the core of governance. Evidence is that these variables are highly correlated with each other and thus, corruption control is an in-alienable policy agenda in modern governance.

\section{Corruption Control And Anti-corruption Agencies}

In fact, the initial efforts to control corruption were taken during the post-world war period by colonial powers and the newly independent states (Sousa, 2010). While the objective of colonial powers for controlling corruption was to clean-up their administration, the newly independent countries endeavoured to undo the corrupt practices rooted in their colonial inheritance by creating Anti-Corruption Agencies (ACAs). The ACAs model was perceived to be a strong institutional response to corruption in the environment of systemic corruption. But, many of the ACAs have fallen short of the expectations they raised (Sousa, 2010) and anti-corruption enforcement in many countries remain inefficient (Jeremy Pope, 2000; Heilbronn, 2004) for different reasons. Studies indicate that the conventional approach of fighting corruption through ACAs faces the problem of weak institutional design in many jurisdictions. For 
Lambsdorff (2007), effectiveness of the anti-corruption enforcement depends upon how the instruments meant for controlling corruption distribute rents and the conditions attached with those rents in achieving the objective of corruption control.

Anti-corruption enforcement becomes inefficient when distribution of power and interests acts as determinant of anti-corruption enforcement. Khan (2007) attributes inefficiency of ACAs to the institutional arrangement in which the ACAs do function. His argument finds support in the studies of De Souza (2010), Pinsker (2001), Pinto et al., (2008) and Quah (2017). Lambsdorff (2000) talks about deliberate attempts to create weak ACAs as the leaders do not have incentives to hold themselves accountable for their decisions. Also, the beneficiaries of corruption networks often seek to neutralize the ACAs by weakening their legal powers (Princeton University, 2014). As a result, in many developing countries, ACAs remain institutionally weak. For example, in the case of Russia, Pinsker (2001) attributes the weak legitimacy of Russian ACA to the need for taking permission from government before investigating higher officials. Quah (2017) argues that Anti-corruption agencies of South Korea and Philippines are toothless because of the unwillingness of governments to fight corruption. Similarly, Indian ACAs have to mandatorily obtain prior administrative approvals from government authorities before investigating as well as prosecuting a public servant in corruption cases (Perumal, K, 2019). The prior approval process suffers from inefficiency; and evidently, there are delays of even thirteen years for granting approvals for prosecuting public servants in corruption cases (Supreme Court of India, 2001).

The United Nations Convention against Corruption (UNCAC)[1] and the Jakarta statement[2]on anticorruption agencies underline the importance of independent ACAs for effective corruption control. According to Quah (2017), ACAs raison d'être is to act as independent watchdogs that investigate all corruption cases impartially without fear or favor regardless of the position, status or political affiliation of those being investigated. Literature show that empowering the ACAs requires certain institutional features that guarantee their functional autonomy. Successful anti-corruption agencies like, the ICAC ${ }^{[3]}$ of Hong Kong, $\mathrm{CPIB}^{[4]}$ of Singapore and OGE $\mathrm{E}^{[5]}$ of the United States of America show that the anti-corruption enforcement need to be functionally independent for efficient corruption control. Functional independence for the ACAs must inevitably include the power to suo moto investigate and to prosecute the corrupt. The ACA of Hong Kong has powers even to incarcerate the suspect in case of risk of flight (Heilbronn J, 2009) and the Malaysian anti-bribery legislation mandates their ACA to examine the practices, systems and procedures of public bodies in order to facilitate the discovery of offence (Malaysian Anti-Corruption Commission, 2016). While explaining the scope of corruption control work done by ACAs in South Asian countries, De Souza (2002) argues that mission of ACAs goes beyond the legal and criminal provisions in force. De Speville, et al., (2013) identify distinctiveness of ACAs from other enforcement agencies as one of the prerequisites for effective corruption control. Powers to initiate action suo moto and to prosecute the corrupt have been cited to be critical for efficient ACAs by many studies. Heilbronn (2004) rightly argues that the ACAs cannot succeed in corruption control in the absence of laws necessary to carry out their activities. 
[1] UNCAC is the only legally binding universal anti-corruption instrument. It came into force in December, 2005.

[2] It's a statement on principles for independent anti-corruption agencies.

[3] Independent Commission against Corruption.

[4] Corrupt Practices Investigation Bureau.

[5] Office of Government Ethics.

\section{Corruption, Corruption Control And Government Organizations}

Ultimately, resources of the state need to be allocated by the agents and a major part of them form bureaucracy. Bureaucracies are formal organizations characterized by hierarchy, division of labor and specialization. Evidence suggest that bureaucracies have the inclination to sustain information asymmetry, which according to the Principal-Agent model, is the cause of corruption. For Souza (n.d), information asymmetry makes bureaucracies powerful as it allows them to allocate resources arbitrarily (Vedung, 2015). Also, the bureaucracies use coping mechanism for prioritizing, restricting, favoring and managing the rents (Aida \& Rzayeva, 2018). In high discretionary environments, information asymmetry and coping mechanism can deepen the problem of corruption. While studying about bureaucracies and corruption clean up strategies in Africa, Mbaku (n.d) argues that bureaucrats' not being constrained by law is the main reason for failure of African anti-corruption agencies. Similar is the experience of corruption control strategies in many developing countries. By drawing correlation between inefficient rules and corruption, Mbaku further argues that bureaucratic corruption is the outcome of inefficient rules. It has been shown that bureaucracies tend to exclude the public, hide its knowledge \& actions from criticism as well as it can (James, 2012). For Downs (1994), bureaucracy fears of outside investigations due to the fear of getting exposed.

Rich literature is available about the two distinct ways in which corruption manifests in public organizations.1.Organization of corrupt individuals where individuals get benefit at the cost of organizations and 2. Corrupt organizations (Ashforth \& Anand, 2003) where corruption is endemic in the organization. Pinto, et al., (2008) attribute failure of internal processes to control corruption for these organizational level phenomena. While emphasizing the role of leadership in controlling corruption, Vardi \& Weitz (2016) argue that leaders who implicitly approve corrupt behaviours of their juniors, even if they do not engage in corruption themselves, encourage corruption in the organization. There are studies showing correlation between organizational culture, ignorant principals and corruption. McKenna (1996) argues that corrupt behaviour is fostered when organizational culture instills notions of impunity in the organization. While explaining the self-reinforcing nature of corruption in organizations, Stephenson (2018) argues that ubiquity of corruption strengthens incentives for individuals to behave corruptly. In specific scenarios ignoring the corrupt behaviours of juniors can even become preferable option for the principal. Mungiu \& Pippidi (2011) support this view by arguing that when corruption is pervasive, principals do not necessarily act in the interest of society and, rather pursue particularistic interests. In high corruption environments to keep quiet \& gradually take part in the practice is usually less costly than blowing the whistle and confronting the corrupt (Amundsen, 1997). 
There are arguments that corruption brings solution to the problem of internal cohesion particularly when the team of public servants is predatory (Kant. R, 2013). Also, corruption acts as hostage mechanism to prevent the probability of defection and insurrection by insiders (Marley, 1998) in organizations. While explaining collusive corruption, Souza (n.d) argues that collusion makes separation of powers ineffective in providing checks and balances. For Andvig and Moene (1990), probability of detecting the corrupt is the decreasing function of the proportion of his colleagues who are also corrupt. Thus, corrupt behaviours have strong links with many underlying factors \& relationships within the organization and supervisors play crucial role in getting the corrupt agents detected.

But, responses of the principals to the corrupt behaviours of their juniors are often influenced both by attitudinal and organizational factors and they respond differently to different types of corrupt behaviours by their agents. Also, the nature of corrupt deal impacts the decision of the principal in reporting for detection; and the higher the probability of the principle getting investigated the lesser likely is the principal would report the instance of corruption for detection by anti-corruption enforcement. This can be explained with the standard corruption typology. The first type of corruption is that which does not violate any legal rules. This is corruption without theft as observed by Shleifer \& Vishney (2014). In its more aggressive form, here the agent may jump the queue for providing the service which could be legal, and as motive or reward the agent may obtain bribe. Since this type of corruption does not distort any policy, there cannot be any evidence in official records showing misconduct by the agent. Nonetheless, since this type of corruption does not harm others in the bureaucracy supervisors may tend to remove the bad apples by referring the matter for detection by ACAs. Here, principals do not see the likelihood of potential harm for themselves or for the organization. The second type of corruption which is known as administrative corruption is that which violates rules. In this type, the bribe giver and agent have clear motives and are well aware of their incentives in their engagement. According to Pradhan et al., (2000), this type of corruption involves intentional distortion of existing institutional rules. Administrative corruption is often not for individual benefits (Ritzvik, 2009), because, in administrative corruption distortions happen at organizational levels. Here, the principal can foresee the likelihood of being held accountable for his/ her failure to prevent rule violations, if not for larger conspiracy. Here, the supervisors tend to exercise their discretions to get the matter addressed within the organization instead of preferring outside investigations.

The third type of corruption is state capture. In state capture, there is misuse of public office for private gain through influence over institution making (Rose-Ackerman, 2008) and reforms (Pradhan et al., 2000; Tudoroiu, 2015. In other words, state capture happens when rules and regulations are devised or changed to suit the interests of the client. Detecting this type of corruption is a challenge because of collusion among multiple actors both within and outside the state (Guha R, 2007). When supervisors and agents are inevitably parties to the deal in state capture, reporting this type of corruption will be detrimental to all the parties. When, the likelihood of getting arraigned as party to the corrupt deal is high, supervisors tend to exercise their discretionary powers to remain insulated from outside investigations. Also, in this scenario investigation is not a preferable choice for the principal. Thus, preferring investigations over the instances of corruption is not natural choice for the principal, and the having the ACAs with legal powers 
to discover the corrupt networks and factors that sustain corruption will go against their interests (Perumal, 2019). Prendergast (2001) rightly argues that bureaucracy resists investigations because investigations will make their activities visible.

\section{Statement Of The Problem: Anti-corruption Enforcement And Administrative Approvals In India}

Like any other developing country, India also has high corruption level. India averaged at 75.67 from 1995 until 2019 with an all-time high of 95 in 2011 in Corruption Perception Index (Transparency International, 2019) and has not substantially improved in ranking thereafter. In the Ease of doing Business Index and Global Governance Index, India stands at 77 and 124 (World Bank, 2018) respectively. These indicators suggest the need for more active anti-corruption enforcement in India. Explaining the problem of corruption in India, Bhushan (2011) argues that corruption in India has grown to alarming proportions because of the policies that have created enormous incentives for its proliferation. Studies suggest that corruption has not come down in India in spite of over seventy years of institutional experience in corruption control through twenty nine specialized anti-corruption agencies.

Explaining the variables under study in this work, Indian anti-corruption legislation, the Prevention of Corruption Act, 1988, as amended in 2018, contains provisions that mandate the Indian ACAs to take prior administrative approvals from government authorities for instituting inquiries, enquiries \& investigations and for launching prosecutions against public servants in corruption cases (Government of India, 2018). Such protections are available for both serving and retired public servants. If an anticorruption agency or a trial court takes cognizance of an offence without prior administrative permission from the government, the action so taken becomes bad in law and the entire activity right from enquiry can get terminated irrespective of the merits of the case. In other words, the Indian ACAs remain dependent on government permissions for launching detections and prosecutions against the public servants in corruption cases. The stated reason for making the ACAs to obtain prior administrative permissions is to protect the honest public servants from frivolous and vexatious prosecutions (Central Vigilance Commission, 2006). The significant aspect of such safe guards that can promote rent seeking behaviours in public organizations is that the authorities competent to grant administrative permissions enjoy discretionary powers in deciding the requests of ACAs and their action/ inaction cannot be questioned even by the judiciary. As a result, there are issues of denial and delay in deciding approvals for investigating and prosecuting corrupt public servants. Though there is a time frame of maximum four months for deciding the requests for sanctions for prosecutions, set by the Supreme Court of India in 1997 (Supreme Court of India, 1997), there are delays in deciding the proposals for prosecution sanctions submitted by the ACAs (Central Vigilance Commission, 2015).

Whether this institutional arrangement for taking prior administrative permissions impacts the professional work of Indian anti-corruption enforcement in tackling unregulated rent allocations \& rent seeking, corrupt motives and opportunity structures that cause and sustain corruption is the objective of this study. In this work, impact of delays in granting approvals on filing charge sheets by the ACAs; 
impact of attitudinal and institutional factors in deciding prior approvals; and discretions exercised by the supervisors in deciding the proposals for prior approvals are being determined in order to understand the effects of these variables on Indian anti-corruption enforcement. Having identified the research problem, this work seeks to answer the following research questions:

1. Do pending administrative sanctions impact the professional work of Anti-corruption agencies in filing charges sheets in corruption cases?

2. Do attitudinal and organisational factors impact the decision of supervisors in punishing the agents on allegations of corruption?

3. Do supervisors across organizations appreciate the prima-facie evidence for investigations by ACAs similarly?

\section{Methodology, Data Collection And Data Description}

If the institutional constraints faced by Indian anti-corruption enforcement cause inefficiency has not sufficiently been studied so far and an interdisciplinary approach by applying concepts like, rents and rent seeking can bring about the politico-economic aspects of corruption control in Indian context. With this objective, this context based exploratory study uses both primary and secondary data for drawing statistical inference. Secondary data were collected from annual reports of National Crime Records Bureau and Central Vigilance Commission, India, covering details of cases 1 . Charge sheeted by the Indian ACAs and 2. Pending for sanctions for prosecution with different public authorities upon completion of investigation by the ACAs. Primary data were collected from four different categories of supervisory level public servants working in three different states viz, Tamilnadu, Bihar and Jharkhand of India. Respondents were selected from banking, police and vigilance agencies in addition to officers belonging to Indian civil services. Police and banking departments were chosen as corruption level is perceived to be high in these sectors. Chief vigilance officers were surveyed as they form essential part of the disciplinary apparatus in every government organization. Officers from the civil services were considered as they are part of the decision making process in deciding prior approval matters. In total, 571 respondents were approached with survey questionnaire and 180 respondents responded. Considering the sample universe size of about 2300 , the sample size is fairly representative. This study uses linear regression, $\mathrm{t}$-test for testing independence and analysis of variance for data for drawing statistical inference considering objectives of the study.

In order to study the impact of pending sanctions for prosecution on the professional work of Indian ACAs data from 2001 onwards were considered as the time frame for deciding the proposals was fixed in late 1997 by the Supreme Court of India. From 2016 onwards the national crime records bureau of India is not publishing data related with pending sanctions for prosecution. Thus, data analysis was limited to the period from 2001-2015 (Annexure- A). In the absence of data regarding the exact period of delay caused by different public authorities in granting sanctions, available data showing the detail of cases pending for prior sanctions was treated as predictor variable. From the number of cases pending for sanction for prosecutions their percentage to the number of cases charge sheeted was calculated. Cases 
pending for sanction for prosecution denote the cases in which investigations were complete and the anti-corruption agencies did await sanctions of the competent authorities for filing charge sheets in trial courts. Proposals for granting sanction for prosecutions are submitted by anti-corruption agencies upon completion of their investigations providing the details of evidences available against the accused public servant. The percentage of cases pending for sanction for prosecutions to the total number of cases charge sheeted could indicate the magnitude of the problem as it did range from 36.9 to 66.8 percent to the cases charge sheeted by various anti-corruption agencies for the period under study.

Pair Plots matrix for each pair of the variables were prepared in order to display the distribution of both the predictor and outcome variables and the relationship between them. Distribution of the variables and their relationships can be visualized as below. Distribution of data points shows the pattern indicating a high negative correlation between the variables under study.

The second research question is about impact of attitudinal and organizational factors on the decisions of supervisors in punishing their juniors for their corrupt behaviours. It is sought to study how these factors act as determinants of corruption control at organizational level. India follows Weberian model of bureaucracy (William, 2017) with formal rules, and the bureaucratic hierarchy has well defined roles for public servants falling under different ranks. Broad categorization of ranks in public departments and organizations in India could be senior level, middle level and lower bureaucracy. Service conditions of different categories of public servants are regulated by their respective service rules and corruption control is one of the fundamental responsibilities of public servants irrespective of their rank. Still, in spite of the presence of institutional arrangements corruption could not be eliminated in public offices as not all the public servants who engage in corruption get detected. Similarly, not all the senior/ supervisory level public servants punish their juniors for their corruption related misconduct. This could explain the paradox in corruption control in public offices.

Whether this "endogenous problem" is organization specific or is experienced across various public organizations could be an interesting area of study because findings on this count can have critical policy implications. In this background, dichotomous data were collected from four different categories of public servants in order to see if the decisions of senior/ supervisory level public servants to let- off their juniors in their corruption related misconduct are by chance or the function of other factors that the principals experience. Categories of public servants selected were 1. Middle level police officers, 2. Vigilance Officers working in various public sector undertakings, 3. Bank Officials and 4. Class-I officers working under both Government of India and under various state governments. Supervisory/ senior level public servants were chosen because they have the authority to reward or punish the public servants working under them as assumed by principal- agent framework. Respondents were requested to answer the question: Have you experienced any of the following justifications for letting off your juniors/ colleagues in their corruption related misconduct? Justifications/ considerations identified were: 1 . Attitude to give opportunity to change; 2 . Empathy due to the personal and professional issues of the junior; 3 . Unavoidability of forgiving the errant junior due to organizational culture; 4 . Attitude that the errant committed mistake for others over whom the supervisor had no control 5 . Tendency to avoid 
associated consequences to others in the organization. 6 . Attitude that punishment is not the solution. 7 . Attitude that punishing a junior will impact owns performance, 8 . Due to loyalty shown by the junior/s and 9. Avoidance of becoming vulnerable due to the connections of the junior/s. Factors identified covered both attitudinal and institutional aspects. The objective was to see if attitudinal and institutional factors impact the decision of the principal in corruption related matters overriding the merits of the incidence of corruption.

Data set shows that police officers experienced more the influence of most of the factors followed by bank officers. This could explain the level of risk involved in their profession and also the organizational culture. Annual reports of Central Vigilance Commission of India also reveal that the highest numbers of denial of sanction for prosecution were consistently from banking sector. This can explain the attitude of banking sector in avoiding criminal investigations into the instances of corruption. The following chart shows the percentage distribution of experience by respondents to the factors under study: (see Figure 2)

The third research question is about appreciating the question of prima-facie evidence sufficient for instituting investigations by supervisors. This aspect remains to be a major cause for delay/ denial of prior approvals for instituting investigations in corruption cases. Often there emerges difference between ACAs and the public authorities in deciding the question of prima-facie evidence. Prima-facie essentially means sufficient at first impression and is the legal requirement for initiating criminal investigations. Prima-facie case simply explains the facts of the offence and subsequent investigations collect evidence to prove or disprove the allegations. Appreciating the prima facie evidence does not require specific legal knowledge and it simply ensures that there are some incriminating facts on record that needs to be investigated upon. But, often, facts considered sufficient for launching criminal investigations by ACAs are not considered so by the public authorities and different options are weighed by them. Such options can range from denial of approvals to asking the ACAs to provide concrete evidence even for launching investigations. In order to study this aspect, a question narrating an instance of corruption in which an ACA wants to launch investigation was prepared. It was intended to study if there was similarity among different categories of public authorities in appreciating the problem and in allowing the ACAs to institute investigation. The question contained those inputs which normally form the basis of registering corruption cases. The requirement of prima-facie evidence was taken into consideration while formulating the question. Also, the question contained officially verifiable facts. Responses to this question were collected from class-I rank officers, vigilance officers, senior level police officers and Bank officials. The question had four options. Class-I level public servants were chosen for this question as they decide/ are involved in the process of deciding the question of prior approval to ACAs for instituting investigations in corruption matters. Vigilance officers were chosen as they play crucial role in vigilance administration in each public department. Senior bank officials were made as respondents as the percentage of denial for sanction for prosecutions has consistently been higher over the period of years and police officers were selected because police have been found to have high level of corruption by various studies. The question under discussion was intended to study if there is similarity across categories of public servants in appreciating the instance of corruption for allowing the ACAs to launch 
investigations. Inter quartile range values calculated for the responses show lesser variation as below: (see Figure 3)

\section{Hypotheses Testing}

This work studies three research objectives covering the following aspects:

1. Impact of pending sanction for prosecutions on the independent professional work of filing charge sheets by Indian ACAs by applying simple linear regression technique.

2. Impact of attitudinal and organizational factors on different categories of supervisors in punishing their agents on corruption charges by applying Chi-square test for independence

3. Differences in appreciating the question of prima-facie evidence by different categories of supervisors in allowing the ACAs for investigations by employing two factors ANOVA test without replication.

\subsection{Prior sanctions for prosecutions and performance of anti corruption agencies}

Null hypothesis $H_{0}$ 1: Filing charge sheets by anti-corruption agencies is not impacted by pending sanction for prosecutions.

Alternative hypothesis: The null hypothesis if false.

In order to estimate the impact of the identified predictor on the dependent variable, year-wise percentage of cases pending for sanction for prosecutions, treated as predictor variable were regressed with the number of cases charge sheeted by the anti-corruption agencies (dependent variable $\mathrm{Y}$ ). Correlation coefficient of -77208 shows high negative correlation between the variables.

As per regression results, multiple correlation coefficient of the model is 0.5961 indicating that about 60 $\%$ variability in the dependent variable is explained by the predictor. The remaining $40 \%$ of the variability could be due to various other factors. For example, in addition to pending sanction for prosecutions, filing charge sheets can be delayed by factors like, late receipt of experts' reports, orders by the higher judiciary etc. This study used analysis of variance (ANOVA) technique for testing the significance of the linear regression model. As per results of analysis, the value of $F$ statistics is 19.1868 and its associated $P$ value is 0.000744 . For the purpose of this analysis, level of significance was kept at 0.05 . Since $P$ value of the model is less than the alpha value of 0.05 , it can be concluded that the relationship that exists between the predictor and outcome variables at $5 \%$ significance level is not by chance and has statistical reasons. In other words, the inference that the issue of pending sanctions for prosecutions impacts the functioning of anti-corruption agencies in India is not random. As per results of analysis, t-statistic for the intercept and slope are 7.778375 and -4.38027 respectively. In both cases, the corresponding P-values are less than the alpha value of 0.05 . Thus, it is concluded that 1 . Values of intercept and slope are not zero and 2. The regression line does not through the origin. Data analysis further shows that $95 \%$ confidence interval for the predictor is $(-100.301,-34.0422)$. This indicates that rate of change in the dependent 
variable lies in the interval $(100.301,-34.0422) 95 \%$ of times when there is a unit change in the predictor. Further, data analysis in this work has helped to evolve a statistical model for quantifying the impact of predictor on the dependent variable. As per regression results, $a=6268.424$ and $b=-67.1714$. Thus, the regression model derived from data analysis is: $Y=-67.1714 \mathrm{X}+6268.424$.

Thus, from data analysis it can be inferred that delay caused in granting sanctions for prosecutions in corruption cases negatively impacts the professional work of anti-corruption agencies in India. In other words, merely by investigating a corruption case, the effectiveness of anti-corruption agencies cannot be improved because, filing charge sheets by the ACAs in India is the function of permissions granted by administrative authorities and the decision to decide prior permissions is external to the anti-corruption enforcement.

\subsection{Attitudinal and Organizational factors as determinants of corruption control}

Null hypothesis H02: Distribution of responses of supervisors in letting off their juniors in their corruption related misconduct is independent of comparison groups. In other words, there is no difference in the distribution of responses to the outcome across comparison groups.

Alternative hypothesis: The null hypothesis is false.

In order to test the null hypothesis, Chi-square tests for independence were done for the responses collected for nine identified factors that possibly influence the decisions of supervisors. The identified factors were independently studied and Chi-square values calculated. Decisions were taken on the basis of critical region approach by comparing the calculated Chi-square values with critical values at $5 \%$ significance level. For studying the null hypothesis, following test statistic was found appropriate as the sample size was large and the expected frequencies were above five for each of the response categories in each group.

$$
\chi^{2}=\sum \frac{[O-E]^{2}}{E}
$$

$(O=$ observed values; $E=$ expected values)

Decision rule: Decision rule in this case was framed on the basis of level of significance and degrees of freedom (df). At $5 \%$ level of significance, the critical chi square value for $d f=3$, is: 7.815 . If Chi-square values are less than the critical value, the null hypothesis will be true. Thus, the decision rule framed is as follows: Reject $H 02$ if the calculated $\chi^{2} \geq 7.815$.

Results of data analysis can be tabulated as below: (see Figure 7)

Since, the calculated Chi- square values for the factors under study are greater than the critical value of 7.815 , the null hypothesis is rejected at $5 \%$ significance level. Thus, it is claimed that the distribution of responses are not independent of comparison groups. In other words, there exists statistically significant 
relationship between the identified factors impacting the decision of supervisors in letting off their juniors of their corruption related misconduct and comparison groups. From data analysis, it can be inferred that factors prompting the decision of supervisors to let off their juniors of their corruption related misconduct need not be based on merits of the case. Such decisions can be subjective and driven by attitudinal and organizational factors. From data analysis, it can further be inferred that, in Indian bureaucratic organizations, getting the instances of corruption related allegations investigated is not the natural choice for supervisors and such decisions are the outcome of a variety of considerations that need not be in consonance with the requirements of rules.

\section{3: Exercising options differently in allowing the anti corruption agencies to investigate instances of corruption}

Null hypothesis: H03 - A: Average effect of responses of various categories of public servants in deciding a prima facie corruption case for criminal investigation is the same.

Null hypothesis: H04 - B: Average effect of different options available for public authorities in deciding a prima facie corruption case for criminal investigation is the same.

Alternative hypotheses: Null hypotheses are false.

Results of analysis of variance are as follow: (see Figure 8)

As per results, $F$ value is larger than the corresponding $F$ critical value with respect to the categories of public servants. Similarly, in the case of different options exercised, $F$ value is larger than the corresponding $F$ critical value. In both the cases, $P$ value is less than 0.05 . Thus, the null hypotheses, H03- A \& H03- B that the average effects of responses of 1 . Categories of public servants and 2. The options exercised by them in deciding a prima facie corruption case for criminal investigation are the same are rejected at the significance level of 0.05 . Since, both the null hypotheses are rejected, pair wise comparison was done to study the statistically significant difference between various pairs of factors, if any. Pair wise comparison results below using randomized block design technique show significant difference between various options weighed by different categories of public authorities in allowing the ACAs for conducting investigations into suspected instances of corruption. (see Figure 9)

From results, it can be inferred that issue of allowing the ACAs to conduct investigations into corruption related allegations is subject to interpretations and appreciation of facts differently by different categories of public authorities. Institutional arrangements that enable different public authorities to interpret the same facts differently and to apply their discretionary powers to weigh convenient options can result in unregulated rent allocations and consequent rent seeking. Such arrangements can distort the performance of anti-corruption enforcement by not allowing them to conduct investigations into the instances of corruption.

\section{Limitations Of The Study And Further Research Possibilities}


Considering resource and time constraints, the study was confined to the available resources. Secondly, data on status of pending proposals for prior approvals and rejected proposals could not be provided by all the ACAs. Though six ACAs responded, data given by them were incomplete. Another challenge that this work faced was though the Indian anti-corruption legislation has the safe guards right from 1947, this problem has not been comprehensively studied so far. This caused the author to develop an entirely new exploratory typology for studying the research problem.

There are promising possibilities to study the procedural efficiency of the administrative approval process itself as the decision of granting prior sanctions remains absolutely discretionary. It would be interesting to study the element of subjectivity and information monopoly etc., in the approval process for better policy prescriptions and for developing context specific interventions. Similarly, if prior approvals really protect honest public servants can also be studied.

\section{Conclusion And Recommendations}

This context based research, aimed at studying the impacts administrative approvals, in-built in the Indian anti-corruption legislation, on the effectiveness of ACAs in India has explored the complex relationships that exist between various variables impacting the decisions of prior administrative approvals for investigating and prosecuting a public servant in corruption cases. Studying different variables and their interaction effects applying appropriate statistical tools provided a sound framework for this research and outcome of the results show that prior approval process is prone to subjectivity prompted by organizational and attitudinal factors and that applying discretions while deciding administrative approvals can result in appreciation of facts differently by different public authorities. Further, this study has demonstrated that engaging in corruption becomes a low risk option when detection remains endogenous to the public offices that decide prior approvals in high discretionary environments; and that high level discretions enjoyed by public authorities in allowing/ restricting the ACAs to investigate the instances of corruption can promote rent seeking behaviour in public organizations.

The Indian anti-corruption legislation does not contemplate punitive action for abusing the process of prior administrative approvals nor have the anti-corruption enforcement legal remedy against unexplained delays and willful denials. If the process of prior sanctions is vulnerable to abuse by remaining unregulated, the critical requirements of corruption control viz, surety of detection and severity of punishment can get compromised. According to the World Bank (2014), combination of high discretion and low accountability can create perverse incentives making the institutions prone to reckless decision making. Theoretically, the absence of binding procedures and lack of punishment for abusing the process of prior approvals can lead to unregulated rent allocations and illegal rent seeking for causing delay or denial of approvals. Thus, holding the authorities that decide the approval matters accountable for their decisions could be a solution to prevent arbitrary decisions. Accountability here must include answerability for the decisions taken and the delay caused. Also, it is necessary to create binding rules for processing administrative approval related matters and such procedures can specify under which 
circumstances approvals can be denied. Similarly, the anti-corruption enforcement can be provided legal powers to appeal against inaction or denial of approvals by administrative authorities. The next prescription would be allowing the anti-corruption agencies to deem approvals granted when their proposals are not decided within the fixed and inflexible time frame. This provision, coupled with powers of the ACAs to appeal against administrative decisions and accountability for the decisions can bring in efficiency to the process.

The global move against corruption recommends giving independence to the anti-corruption enforcement with adequate legal powers. Functionally autonomous anti-corruption agencies elsewhere have proven to be efficient in corruption control. With corruption becoming global and complex, the anti-corruption enforcement must be armed with progressive legislations that can efficiently address the challenge. Thus, making the Indian anti-corruption enforcement functionally independent will eventually help India to fight corruption better in days to come.

\section{Declarations}

\section{Pledge of Honesty/Declaration.}

- I pledge on my honor that I have not plagiarized or used unauthorized materials in this work nor do I not have any conflict of interest in this academic work nor have I been funded by anybody for writing this article.

- I am the author of this research article and

- The paper is original and it has neither been accepted for publication/published elsewhere and nor has been submitted for consideration for publication in any other journal.

- I have not received any grant/fund for this article and I have no conflict of interest in this work.

\section{References}

1. Aida \& Rzayeva. (2018). The role of e-government in reduction of information asymmetry in developing countries on the example of Azerbaijan. Advances in Economics and Business, 2018: 209-217.

2. Amundsen, I., 1997. Political corruption: an introduction to the issues. 1st ed. Bergen, Norway: Chr. Michelsen Institute.

3. Andrews, et al., (2016). The big stuck in state capability for policy implementation. Centre for International Development,Harvard University.

4. Bhushan, P., (2011, September). Dealing with mega corruption. www.india.seminar.com

5. Blackburn. (n.d). Endogenous corruption in economic development. Milwaukee: Department of Economics, University of Wisconsin.

6. Central Vigilance Commission. (2015). Guidelines for checking delay in grant of sanction for prosecution. New Delhi: Central Vigilance Commission. 
7. Chassang. (2016). Decision theoretic approaches to experiment design and external validity.Abhijit Banerjee.

8. Dunn, J. \& Schweitzer, M. E., (2004). Why good employees make unethical decisions. In: J. Ronald E. Kidwell \& C. L. Martin, eds. Managing organisational deviance. New Delhi: SAGE Publications, pp. 3961.

9. El-Ayouty, Y., (2003). Combating corruption for development: the rule of law, transparency and accountability. Westport: Greenwood Publishing Group.

10. Fischer. (2004). Macroeconomics. New York: McGraw \& Hill.

11. Government of India. (2003). Available at: <http://legislative.gov.in: http://legislative.gov.in/sites/default/files/A1946-25.pdf>

12. Government of India. (2018). [Online] Available at: <http://www.egazette.nic.in/WriteReadData/2018/187644.pdf>

13. Heilbrunn, J. R., (2004). Anti-corruption commissions:panacea or real medicine to fight corruption? Washington: World Bank Institute.

14. Jhonston. (1998). Fighting systemic corruption: social foundations for institutional reform. European Journal of Development Research .

15. Khan, M., (2004). Determinants of corruption in developing countries: the limits of conventional economic analysis. Susan: Rose-Ackerman.

16. Khan, M., (2006). Governance and anti-corruption reforms in developing countries: policy, evidence and ways forward. New York: United Nations .

17. Kleibrink, A., (2015). Political elites and decentralization reforms in the post-socialist states. 1 st ed. London: Palgrave Macmillan.

18. Klitgaard, R., (1988). Controlling corruption. Berkley CA: University of California Press.

19. Kreuger. (1994). The political economy of policy reform in developing countries. MIT Press.

20. Lambsdorff, J., (2000). Making corrupt deals: contracting in the shadow of the law. Journal of Economic Behaviour and Organizations , 221-241.

21. Lambsdorff, J., (2002). Corruption and rent seeking. In Lambsdorff.J.G, Public choice (pp. 97-125). Gottingen: Universitat Gottingen, Germany.

22. Lambsdorff, J., (2007). The institutional economics of corruption. Cambridge: Cambridge University Press.

23. Madema, S. (2015). Market failure in context: introduction. History of Political Economy, 1-19.

24. Maesschalck, J. \& Bertok, J., (2009). Towards a sound integrity framework: instruments,processes, structures and conditions for implementations. Paris: OECD.

25. Malomo. (2013). Factors influencing the propensity to bribe and size of bribe payments: evidence from formal manufacturing firms in West Africa. Sussex: University of Sussex.

26. Malaysian Anti-Corruption Commission. (2016). www.sprm.gov.my. [Online] Available at: <https://www.sprm.gov.my/index.php/en/corporate-info/mengenai-sprm/organization- 
info/functions>

27. Mbaku, J. (2003). Bureaucratic and political corruption in Africa: the public choice perspective. International Journal of African Historical Studies , 427-456.

28. Mbate, M., (2016). Who bears the burden of bribery? evidence from public service delivery in Kenya. London: Department of International Development, London School of Economics and Political Science.

29. Mungiu, \& Pippidi. (2011). Contextual choices in fighting corruption: lessons learned. Norweigian Agency for Development Cooperation.

30. OECD, (2012). http://www.oecd.org. [Online] Available at: http://wWw.oecd.org/cleangovbiz/toolkit/50042935.pdf [Accessed 09 August 2019].

31. Olken,et al., (2011). Corruption in developing countries. Research paper, Harvard: Harvard University, 2011.

32. Panth, S., (2011). Changing norms is a key to fight everyday corruption. Washington: International Bank for Reconstruction and Development.

33. Perumal, K., 2019. Corruption measurements: caught between conceptualizing the phenomenon and promoting new governance agenda? Research article. The Journal of Business Perspectives, 1-8.

34. Perumal, K., 2019. State capacity, drivers of corruption and anti-corruption interventions: contextualizing corruption in Indian context- a rational choice approach. Review article: International Journal of Development Research,IX(11), 3323-3330.

35. Persson, A. \& Bo Rothstein. (n.d) Comparative Politics. In: persson--rothstein, ed. Comparative Politics. s.l.:https://qog.pol.gu.se, pp. 231-249.

36. Pinto, et al., (n.d.). Corrupt organizations or organization of corrupt individuals? two types of organization level corruption. Academy of Management Review, 685-709.

37. Princeton University. (n.d). What is political economy? New Jersey: Princeton University Press.

38. Quah, J. S., (2017). Anti-corruption agencies in Asia-Pacific countries. Singapore: Transparency International.

39. Schwertheim, H., (2017). Innovation in anti-corruption approaches. Stromsborg: Institute for Democracy and Electoral Assistance.

40. Singh, B., (2008). The challenge of good governance in India: need for innovative approaches. New York: John Kennady School of Governance, Harvard University.

41. Sousa, L., (2010). Anti-corruption agencies: between empowerment and irrelevance. Crime, Law and Social Change, 5-22.

42. Supreme Court of India. (1997). Vineet Narain \& others Vs Union of India (Barucha, S.C. Sen December 18, 1997).

43. Supreme Court of India. (2001). Mahendra Lal Das Vs State of Bihar, 1038/ 2001 (M.B Shah, R.P Sethi October 12, 2001). 
44. Transparency International. (2019). Anti-corruption agencies assessment and methodology. Berlin: Transparency International.

45. Tullock. (1993). Corruption: theory and practice. Contemporary Economic Policy , 6-13.

46. United Nations Industrial Development Organisation, (2011). UNIDO. [Online] Available at:< https://www.unido.org/news/unido-report-offers-global-connectedness-ranking-saysknowledge-networks-can-achieve-development-goals>

47. Vardi, Y. \& Weiner, Y., (2016). Misbehaviour in organisations. Organization Science, March-April, VII(2), pp. 151-165.

48. William. (2017). Ascending India and its state capacity- extraction, violence and legitimacy. New Haven: Yale University Press.

49. World Bank.(2014). [Online] Available at: <https://tcdata360.worldbank.org/indicators/hc153e067? country $=$ BRA\&indicator $=364 \&$ viz=line_chart\&years $=1996,2017>$

50. WorldBank.(2018). [Online] Available at: <https://tcdata360.worldbank.org/indicators/hc153e067? country=BRA\&indicato364\&viz=line_chart\&years=1996,2017>

\section{Figures}
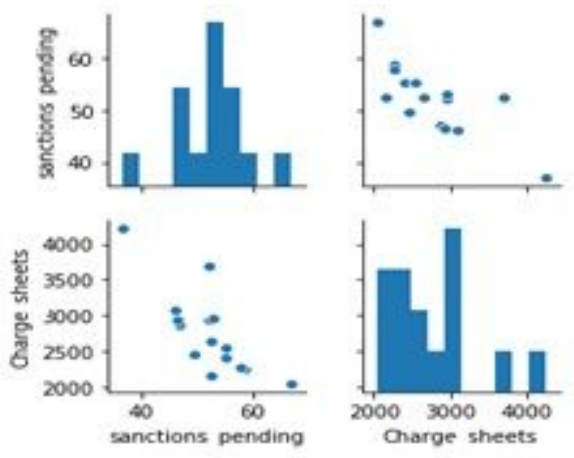

\section{Figure 1}

Pair plot matrix for pending sanctions and charge sheets. 


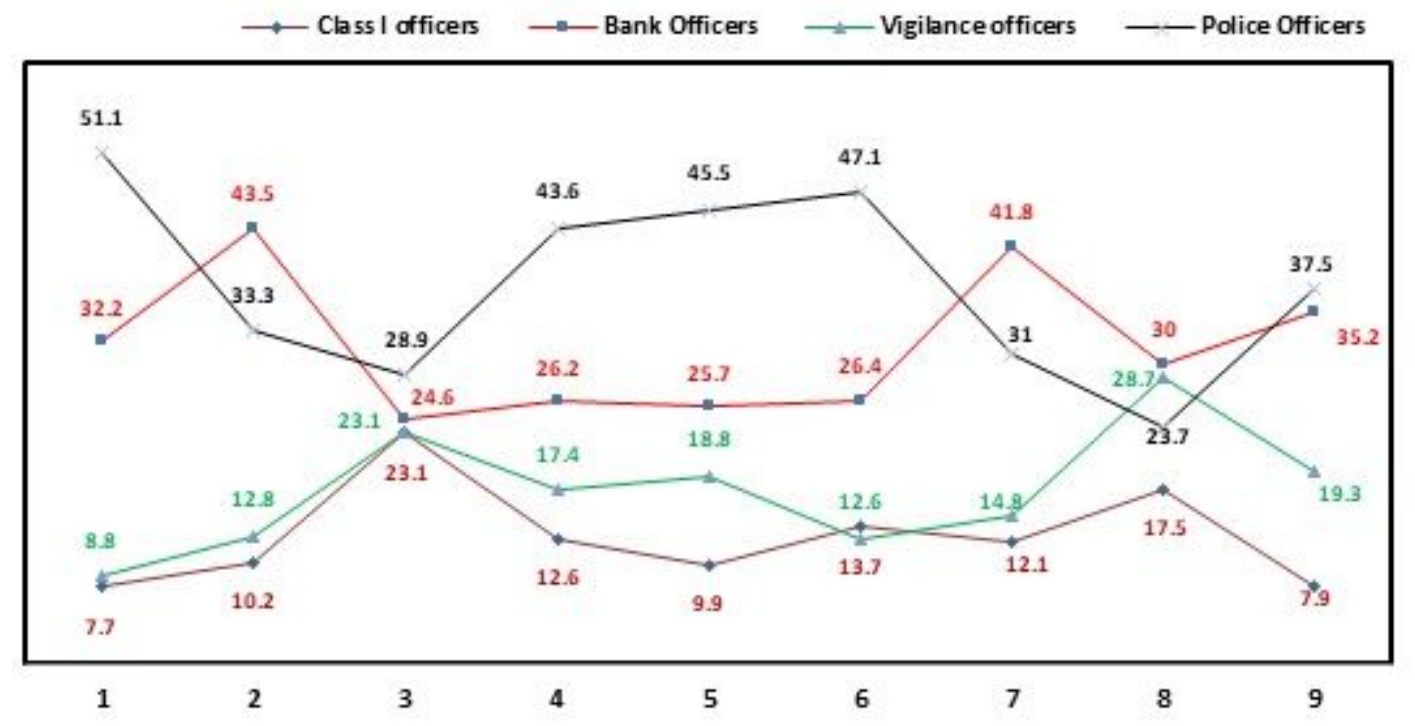

\section{Figure 2}

Percentage distribution of respondents who experienced influence by various factors

\begin{tabular}{|c|c|c|c|c|}
\hline \multirow{2}{*}{ Category of respondents } & \multicolumn{4}{|c|}{ Inter-quartile range values } \\
\cline { 2 - 5 } & $\mathrm{A}$ & $\mathrm{B}$ & $\mathrm{C}$ & $\mathrm{D}$ \\
\hline Class I & 2 & 0.5 & 0 & 0.55 \\
\hline Vigilance Officers & 0.875 & 1 & 0.95 & 1.375 \\
\hline Bank Officers & 0.5 & 0.5 & 0 & 0.5 \\
\hline Police & 0.6 & 0.5 & 0.5 & 0.3 \\
\hline
\end{tabular}

\section{Figure 3}

Inter-quartile range values

\section{Charge Sheets Vs Pending sanctions}

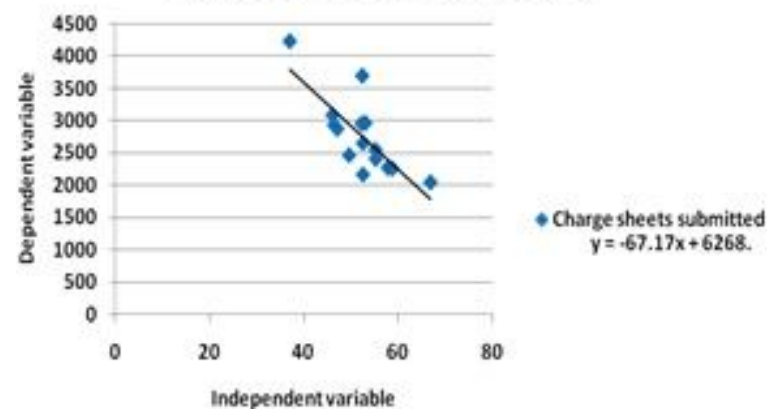

\section{Figure 4}

Regression plot 


\begin{tabular}{|l|l|}
\hline \multicolumn{2}{|l|}{ Figure-4: Regression Statistics } \\
\hline Multiple R & 0.77208 \\
\hline R Square & 0.596108 \\
\hline Adjusted R Square & 0.565039 \\
\hline Standard Error & 389.141 \\
\hline Observations & 15 \\
\hline
\end{tabular}

\section{Figure 5}

Regression results

\begin{tabular}{lrrrrll}
\hline \multicolumn{1}{c}{ DF } & SS & MS & $\boldsymbol{F}$ & \multicolumn{2}{l}{ Significance $\boldsymbol{F}$} \\
\hline Regression & 1 & 2905471 & 2905471 & 19.1868 & 0.000744 & \\
Residual & 13 & 1968599 & 151430.7 & & & \\
Total & 14 & 4874070 & & & & \\
& Coefficients & Standard & $\boldsymbol{t}$ Stat & P-value & Lower $95 \%$ & Upper \\
& & Error & & & & \\
Intercept & 6268.424 & 805.8783 & 7.778375 & $3.04 \mathrm{E}-06$ & 4527.43 & 8009.419 \\
$\begin{array}{l}\text { Percentage of } \\
\text { sanctions pending }\end{array}$ & -67.1714 & 15.33498 & -4.38027 & 0.000744 & -100.301 & -34.0422 \\
\hline
\end{tabular}

\section{Figure 6}

ANOVA table

\begin{tabular}{|l|r|}
\hline \multicolumn{1}{|c|}{ Factors } & Calculated \& critical $\chi^{2}$ values \\
\hline Attitude to give opportunity to change & $22.319200000000002 \geq 7.815$ \\
\hline Empathy due to the personal and professional issues of the junior & $24.130875770000003 \geq 7.815$ \\
\hline Unavoidability of forgiving the errant junior due to organizational culture & $8.73800742 \geq 7.815$ \\
\hline $\begin{array}{l}\text { Attitude that the errant committed mistake for others over whom the } \\
\text { supervisor had no control }\end{array}$ & $30.97794236 \geq 7.815$ \\
\hline Tendency to avoid associated consequences to others in the organization & $12.18913649 \geq 7.815$ \\
\hline Attitude that punishment is not the solution & $17.10278736 \geq 7.815$ \\
\hline Attitude that punishing a junior will impact own's performance & $13.857508840000001 \geq 7.815$ \\
\hline Due to loyalty shown by the junior/s & $9.46985016 \geq 7.815$ \\
\hline Avoidance of becoming vulnerable due to the connections of the junior/s & $11.17400053 \geq 7.815$ \\
\hline
\end{tabular}

\section{Figure 7}

Factors \& Chi square values

\begin{tabular}{lrrrrrr}
\hline $\begin{array}{l}\text { Source of } \\
\text { Variation }\end{array}$ & \multicolumn{1}{c}{ SS } & Df & MS & \multicolumn{1}{c}{$F$} & P-value & \multicolumn{1}{c}{ F crit } \\
\hline Rows & 75.60431 & 3 & 25.20144 & 47.01635 & $8 \mathrm{E}-06$ & 3.862548 \\
Columns & 10.28656 & 3 & 3.428855 & 6.396947 & 0.013044 & 3.862548 \\
Error & 4.824129 & 9 & 0.536014 & & & \\
Total & 90.715 & 15 & & & & \\
\hline
\end{tabular}


Figure 8

ANOVA

\begin{tabular}{|c|c|c|c|c|c|c|c|c|}
\hline $\begin{array}{c}\text { Pairs (Options } \\
\text { exercised) }\end{array}$ & ni & nj & $\mathrm{Ti}$ & $\mathrm{Tj}$ & |Ti-Tj| & $\mathbf{P}$ & CD & Inference \\
\hline $\mathrm{AB}$ & 4 & 4 & 3.06255 & 7.4972 & 4.43465 & 2.13145 & 1.103439 & Significant \\
\hline $\mathrm{AC}$ & 4 & 4 & 3.06255 & 8.6678 & 5.60525 & 2.13145 & 1.103439 & Significant \\
\hline $\mathrm{AD}$ & 4 & 4 & 3.06255 & 7.783225 & 4.720675 & 2.13145 & 1.103439 & Significant \\
\hline $\mathrm{BC}$ & 4 & 4 & 7.4972 & 8.6678 & 1.1706 & 2.13145 & 1.103439 & Significant \\
\hline $\mathrm{BD}$ & 4 & 4 & 7.4972 & 7.783225 & 0.286025 & 2.13145 & 1.103439 & Insignificant \\
\hline $\mathrm{CD}$ & 4 & 4 & 8.6678 & 7.783225 & 0.884575 & 2.13145 & 1.103439 & Insignificant \\
\hline \multicolumn{9}{|c|}{$A, B, C$ and $D$ represent the options exercised by the supenvisors in referring a case for investigation by $A C A s$. } \\
\hline $\begin{array}{l}\text { Pairs } \\
\text { (Supervisor } \\
\text { categories) } \\
\end{array}$ & ni & nj & $\mathrm{Ti}$ & $\mathrm{Tj}$ & $|\mathrm{Ti}-\mathrm{T} j|$ & $\mathbf{P}$ & CD & Inference \\
\hline Class- 1, CVO & 4 & 4 & 7.5444 & 5.45775 & 2.08665 & 2.13145 & 1.103439 & Significant \\
\hline Class- 1, Bank & 4 & 4 & 7.5444 & 7.27015 & 0.27425 & 2.13145 & 1.103439 & Insignificant \\
\hline Class- 1, Police & 4 & 4 & 7.5444 & 6.738475 & 0.805925 & 2.13145 & 1.103439 & Significant \\
\hline CVO, Bank & 4 & 4 & 5.45775 & 7.27015 & 1.8124 & 2.13145 & 1.103439 & Significant \\
\hline CVO, Police & 4 & 4 & 5.45775 & 6.738475 & 1.280725 & 2.13145 & 1.103439 & Significant \\
\hline Bank, Police & 4 & 4 & 7.27015 & 6.738475 & 0.531675 & 2.13145 & 1.103439 & Insignificant \\
\hline
\end{tabular}

Note: ni: Total counts for categories of public servants; nj: Total counts for options exercised; Ti: Mean value for categories of public servants; $\mathrm{Tj}$ : Mean value for options exercised; $|\mathrm{Ti}-\mathrm{Tj}|=\mathrm{Absolute}$ difference between mean values of categories of public servants and options exercised; $t=T$ abulated value of the $t$-distribution; $C D=$ Critical difference of the mean values for each pair of the level of the factor, Inference: Comparison between $\left|T_{i}-T_{j}\right|$ and $C D$. If $\left|T_{i}-T_{j}\right|$ is greater than $C D$, the difference between the average effects of two factors is significant)

\section{Figure 9}

Pair wise comparison 